\title{
FAKTOR-FAKTOR YANG BERHUBUNGAN DENGAN KUALITAS HIDUP PASIEN TB PARU DI RUMAH SAKIT KHUSUS PARU LUBUK ALUNG SUMATERA BARAT
}

\author{
Melti Suriya \\ STIKes Alifah Padang, Jln. Khatib Sulaiman no 52B \\ Email: melti_s85@yahoo.com
}

\begin{abstract}
Abstrak
Kualitas hidup merupakan persepsi seseorang terhadap standar dan harapan hidup, kualitas hidup buruk sering dialami oleh penyakit kronis khususnya TB Paru. Rumah Sakit Khusus Paru Sumatera Barat merupakan Rumah Sakit dengan jumlah kunjungan penderita TB paru terbanyak tahun 2016 yaitu 1016 orang. Tujuan penelitian untuk mengetahui Faktor-faktor yang berhubungan dengan Kualitas Hidup Pasien TB Paru di Rumah Sakit Khusus Paru Lubuk Alung Sumatera Barat. Jenis penelitian adalah analitik dengan desain cross sectional. Populasi dalam penelitian ini adalah seluruh pasien TB Paru yang berobat di Rumah Sakit Khusus Paru Lubuk Alung Sumatera Barat. Pengumpulan data penelitian dilakukan pada tanggal 21 Juni - 21 Juli 2017. Data dikumpulkan dengan menggunakan kuesioner. Teknik pengambilan sampel simple random block sampling dengan sampel 96 orang. Data dianalisis secara univariat dan bivariat dengan uji Chi-Square. Hasil penelitian menemukan bahwa lebih dari separoh (63,5\%) pengobatan lanjutan, lebih dari separoh $(66,7 \%)$ tidak mendapat dukungan keluarga, lebih dari separoh (57,3\%) mengalami depresi, lebih dari separoh $(62,5 \%)$ kualitas hidup pasien TB buruk. Ada hubungan lama pengobatan dengan kualitas hidup pasien TB paru nilai p value 0,000 (p<0,05). Ada hubungan dukungan keluarga dengan kualitas hidup pasien TB paru nilai p value 0,000 (p<0,05). Ada hubungan depresi dengan kualitas hidup pasien TB paru di Rumah Sakit Khusus paru Sumatera Barat Lubuk Alung nilai p value ( $p<0,05)$. Lama pengobatan, dukungan keluarga dan depresi mempengaruhi kualitas hidup pasien TB. Untuk meningkatkan kualitas hidup pasien TB perlunya dukungan dari keluarga, pengobatan yang sesuai aturan dan menghindari depresi pada pasien TB sehingga pasien TB akan memperoleh kesehatan yang optimal baik fisik maupun psikologis. Diharapkan kepada peneliti selanjutnya dapat melanjutkan penelitian ini dengan faktor lain yang mempengaruhi kualitas hidup pasien TB. Quality of life is a person's perception and expectations of living standards, poor quality of life is often experienced by chronic diseases, especially pulmonary TB. Special Hospital Pulmonary Hospital West Sumatra is the number of visits pulmonary tuberculosis patients most in 2016 is 1016 people. The aim of research to determine the factors associated with pulmonary TB Patient Quality of Life in Lung Special Hospital West Sumatra Lubuk Alung. This type of research is analytic with cross sectional design. The population in this study were all pulmonary TB patients who seek treatment at Special Hospital Pulmonary West Sumatra. Data research collection was performed on 21 June to 21 July 2017 data was collected using a questionnaire. The sampling technique is simple random block sampling with a sample of 96 peolpe. Data was analyzed by univariate and bivariate with Chi-Square test. The study found that more than half (63.5\%) continued treatment, more than half $(66.7 \%)$ did not receive the support of the family, more than half (57.3\%) experienced depression, more than half $(62.5 \%)$ quality of life of poor TB patients. There is a long-standing relationship with the treatment of pulmonary tuberculosis patients' life quality p value of 0.000 ( $p<0.05)$. There is a relationship of family support and quality of life of patients with pulmonary TB $p$ value of 0.000 ( $p<0.05)$. There is a relationship of depression with quality of life of patients with pulmonary tuberculosis in the lungs Special Hospital West Sumatra Lubuk Alung $p$ value ( $p<0.05)$. Duration of treatment, family support and depression affect the quality of life of patients with TB. To improve the quality of life of TB patients need the support of family, treatment according to the rules and avoid depression in patients with TB so that TB patients will receive optimal health both physically and psychologically. It is expected that further research can continue this research with other factors that affect the quality of life of patients with TB.
\end{abstract}

Kata kunci : Lama Pengobatan, Dukungan Keluarga, Depresi, Kualitas hidup

Keywords: Old Medicine, Family Support, Depression, Quality of life 


\section{PENDAHULUAN}

TB paru adalah penyakit menular yang disebabkan oleh kuman TB (Mycrobacterium tuberculosis). TB paru adalah penyakit yang dapat menular melalui udara (airbone disease) (Ardiansyah, 2012).

Berdasarkan Global Report WHO 2013 terdapat 236.026 kasus TB dan setiap tahunnya terdapat 197.000 kasus baru TB menular (BTA positif). Padahal setiap penderita TB BTA positif yang tidak segera diobati dapat menular kepada 10-15 orang pertahun. Disamping tingginya penularan, penyakit TB juga menyebabkan tingginya angka kematian yaitu 175 orang setiap hari atau 64.000 orang setiap tahun (WHO, 2013).

Indonesia sekarang sudah berada pada rangking kelima negara dengan beban TB tertinggi di dunia yang mana sebelumnya berada pada rangking tiga. Jumlah kematian akibat TB Diperkirakan 61.000 kematian per tahunnya (Menkes RI, 2013). Penurunan kasus TB terjadi dikarenakan program pengendalian TB terutama DOTS berjalan dengan baik sehigga terjadinya penurunan penderita TB.

Prevalensi penduduk Indonesia yang didiagnosis TB paru oleh tenaga kesehatan tahun 2013 adalah 0,4\%. Provinsi dengan TB paru tertinggi adalah Jawa Barat $(0,7 \%)$, Papua $(0,6)$, DKI Jakarta $(0,6 \%)$. Gorontalo $(0,5 \%)$. Banten $(0,4 \%)$ dan Papua Barat $(0,4 \%)$. Dimana Provinsi Sumatera barat didiagnosis TB paru sebanyak 0,2 \% yang berada di urutan ke-18 dan target pencapaian MDGs yaitu 70,0\% (Riskesdas, 2013). Dari data tersebut Sumatera Barat berada di urutan ke-18 masih diperlukan usaha untuk mengurangi angka penderita TB sehingga posisi Sumatera Barat tidak masuk ke dalam 20 besar.

Penderita TB Paru yang berada pada usia produktif (15-50 tahun) yaitu berkisar $75 \%$. Seorang pasien TB paru dewasa diperkirakan akan kehilangan rata-rata waktu kerjanya 3-4 bulan sehingga berakibat pada kehilangan pendapatan rumah tangga yaitu berkisar 20-30\%. Jika seseorang meninggal akibat tuberkulosis, maka dia akan kehilangan pendapatannya sekitar 15 tahun. Selain merugikan secara ekonomis, TB paru juga memberikan dampak buruk lainnya, yaitu dikucilkan masyarakat (stigma) (WHO, 2012).

Kualitas hidup didefinisikan sebagai persepsi individu mengenai posisi mereka dalam konteks budaya dan sistem nilai dimana mereka hidup dalam kaitannya dengan tujuan, harapan, standar dan perhatian mereka. (Nursalam, 2013). Peningkatan kualitas hidup adalah hal penting sebagai tujuan pengobatan dan merupakan kunci untuk kesembuhan penderita TB paru. Sejumlah orang dapat hidup lebih lama, namun dengan membawa beban penyakit menahun atau kecacatan, sehingga kualitas hidup menjadi perhatian pelayanan kesehatan (Yunikawati, 2013).

Menurut Ratnasari menyatakan fenomena di masyarakat sekarang ini adalah masih adanya anggota keluarga yang takut apalagi berdekatan dengan seseorang yang disangka menderita tuberkulosis paru, sehingga muncul sikap berhati-hati secara berlebihan, misalnya mengasingkan penderita, tidak mau mengajak berbicara, kalau dekat dengan penderita akan segera menutup hidup dan sebagainya. Penderita akan tertekan dan merasa dikucilkan, sehingga dapat berdampak pada kondisi psikologisnya 
dan akhirnya akan mempengaruhi keberhasilan pengobatan, keluhan psikologis ini akan mempengaruhi kualitas hidupnya.

Kualitas hidup terdiri dari beberapa dimensi yaitu dimensi fisik seperti aktivitas sehari-hari, ketergantungan obat-obatan dan bantuan medis, energi dan kelelahan, mobilitas, sakit dan ketidaknyamanan, tidur dan istirahat, serta kapasitas kerja, dimensi hubungan sosial mencakup relasi personal, dukungan sosial, aktivitas sosial, dimensi psikologis mencakup bodily dan appearance, perasaan negative, perasaan positif, self- esteem, berfikir, belajar, memori dan konsentrasi, dimensi lingkungan mencakup sumber finansial, freedom, physical safety dan security, perawatan kesehatan dan social care, lingkungan rumah, kesempatan untuk mendapatkan berbagai informasi baru dan keterampilan, partisipasi dan kesempatan untuk melakukan rekreasi atau kegiatan yang menyenangkan (WHO (1996) dalam Nursalam (2013).

Menurut Darmanto (2007) adanya masalah pada fisik, mental (emosional), dan sosial akibat penyakit atau gangguan kesehatan dapat mengakibatkan penurunan kualitas hidup. Brazier pada tahun 1996 (dalam afiyah 2010) melakukan studi di inggris beberapa faktor mempengaruhi kualitas hidup dan didapatkan hasil sebagai berikut seseorang dengan penyakit kronik akan mempunyai kualitas hidup yang lebih buruk, seseorang dengan usia 65-67 tahun mempunyai kualitas hidup yang buruk, wanita yang mempunyai masalah depresi dan cemas lebih tinggi cenderung mempunyai kualitas hidup yang buruk.

Menurut Nazir (2006) faktor lain yang mempengaruhi kualitas hidup seperti kesehatan, keuangan, keamanan, keadaan lingkungan, dukungan keluarga dan lingkungan sekitar. Menurut Unalan, et al (2008). lama pengobatan juga dapat mempengaruhi kualitas hidup pasien tuberkulosis. Proses pengobatan tuberkulosis membutuhkan waktu minimal 6 bulan (Depkes RI, 2008).

Menurut Stuart dan Sundeen (1995) dalam Tamher (2009) bahwa dukungan dari keluarga merupakan unsur terpenting dalam membantu individu menyelesaikan masalah. Adanya dukungan keluarga akan meningkatkan rasa percaya diri dan motivasi untuk menghadapi masalah.

Keluarga adalah pendukung utama yang memberikan perawatan langsung pada setiap keadaan sehat-sakit anggota keluarganya. Dalam memberikan dukungan terhadap salah satu anggota keluarga yang menderita suatu penyakit, dukungan dari seluruh anggota keluarga sangat penting dalam proses penyembuhan dan pemulihan penderita (Friedman, 2010). Dukungan emosional dukungan diberikan berupa kepedulian keluarga terhadap anggota keluarga yang mengalami penyakit kronik khususnya penyakit TB. Dukungan penghargaan, yang terjadi lewat pujian positif untuk kepatuhan minum obat, dukungan instrumental berupa menemani anggota keluarga yang sakit untuk berobat dan dukungan informasi pada penderita TB yaitu keluarga mengetahui apa saja informasi kesehatan yang terkait dengan Penyakit yang diderita oleh anggota keluarga khususnya TB paru.

Rumah Sakit Khusus Paru Lubuk Alung merupakan rumah sakit khusus untuk penyakit paru-paru. Kunjungan kasus penyakit paru di poliklinik untuk kasus paru sebanyak 16.351. Kunjungan penderita TB BTA (+) baru dari 17 
kabupaten/kota terbanyak adalah dari Kabupaten Padang Pariaman sebanyak 289 jiwa, disusul Kabupaten Pasaman Barat sebanyak 163 jiwa, dan diurutan ketiga Kabupaten Pesisir Selatan sebanyak 128 jiwa (Profil RS Khusus Paru Lubuk Alung 2015).

Berdasarkan data tahun 2013 pengidap BTA (+) sebanyak 1177 orang, pada tahun 2014 pengidap BTA (+) yaitu 919 orang dimana telah terjadi penurunan penderita TB dikarenakan program DOTS yang telah dijalankan pemerintah berjalan dengan baik dan pada tahun 2016 pengidap BTA (+) terjadi peningkatan yaitu 1016 orang. (Laporan Tahunan RS Khusus Paru Lubuk Alung 2015).

Hasil Penelitian yang dilakukan oleh Nita Ratnasari (2012) dengan judul hubungan dukungan sosial dengan kualitas hidup pasien TB di BP4 Yogyakarta Unit minggiran menyatakan bahwa $68 \%$ penderita TB mempunyai kualitas hidup baik, 30\% penderita mempunyai kualitas hidup sedang dan $2 \%$ penderita TB mempunyai kualitas hidup jelek. Kualitas hidup penderita TB akan semakin baik jika orang-orang disekitar memberikan dukungan, semangat dan motivasi untuk kesembuhannya.

Menurut penelitian yang dilakukan oleh Putri (2015) didapatkan kualitas hidup baik $23,8 \%$, buruk $76,2 \%$, maka kualitas hidup seseorang penderita TB akan berdampak terhadap keberhasilan pengobatan yang dilakukan oleh penderita TB. Semakin baik kualitas hidup seorang penderita TB, maka akan semakin baik pula kesehatan yang akan diterima oleh penderita TB.

Hasil Survei awal yang dilakukan pada tanggal 1 Februari 2017 di Rumah Sakit Khusus Paru Lubuk Alung Sumatera Barat terhadap 10 orang pasien
6 orang $(60 \%)$ diantaranya mengatakan selama sakit sulit dalam melakukan aktifitas dikarenakan penyakit TB yang diderita. Selain itu klien merasa lemah, sehingga tidak dapat bekerja untuk menafkahi keluarganya. klien merasa malu untuk berkomunikasi dengan lingkungan sekitar, dikarenakan penyakit yang diderita dapat menular ke orang lain. Selain itu 2 orang (20\%) mengalami gangguan mental dan emosional seperti merasa murung, sedih, takut, cemas kalau penyakit yang diderita tidak dapat disembuhkan. Sebanyak 2 orang (20\%) mengatakan bahwa selama sakit keluarga selalu mengantarkan klien untuk pergi berobat khususnya ke Rumah Sakit Khusus Paru dan keluarga juga mengingatkan untuk selalu minum obat dan berobat. Dari 10 orang penderita TB paru yang diwawancarai, sebanyak 4 orang $(40 \%)$ menjalani pengobatan tahap intensif (12) bulan dan 6 orang (60\%) menjalani pengobatan tahap lanjutan (3-6) bulan.

Berdasarkan latar belakang diatas, maka peneliti tertarik melakukan penelitian tentang Faktor-faktor yang berhubungan dengan kualitas hidup pasien TB paru.

\section{METODE PENELITIAN}

Penelitian ini dilakukan untuk mengetahui faktor-faktor yang berhubungan dengan kualitas hidup pasien TB paru di Rumah Sakit Khusus Paru Lubuk Alung Sumatera Barat Penelitian ini menggunakan metode analitik dengan pendekatan cross sectional study. Jumlah Sampel sebanyak 96 orang dan teknik pengambilan sampel dengan simple Random Blok Sampling. 


\section{HASIL DAN PEMBAHASAN}

Tabel 1.1Distribusi Frekuensi Lama Pengobatan Pasien TB Paru di Rumah Sakit Khusus Paru Sumatera Barat Lubuk Alung

\begin{tabular}{llll}
\hline No & $\begin{array}{l}\text { Lama } \\
\text { Pengobatan }\end{array}$ & frekuensi & $\%$ \\
\hline 1 & $\begin{array}{l}\text { Intensif }(1-2 \\
\text { bulan) }\end{array}$ & 35 & 36,5 \\
2 & $\begin{array}{l}\text { Lanjutan }(3-4 \\
\text { bulan) }\end{array}$ & 61 & 63,5 \\
\hline & Total & 96 & 100,0 \\
\hline
\end{tabular}

Berdasarkan tabel 1.1 diatas dapat diketahui bahwa dari 96 orang responden terdapat lebih dari separoh $(63,5 \%)$ dengan lama pengobatan lanjutan.

Lama pengobatan yang dilakukan penderita TB ada 2 tahap yaitu tahap Intensif (1-2 bulan) dan tahap lanjutan (36 bulan). Pada tahap intensif pasien mendapat obat setiap hari dan perlu diawasi secara langsung untuk mencegah terjadi resistensi obat. Sedangkan tahap lanjutan pasien diberikan obat lebih sedikit namun dalam jangka waktu yang relatif lama (Menkes RI,2011)

Tujuan pengobatan pada penderita TB paru, selain untuk mengobati juga untuk mencegah kematian, kekambuhan dan resistensi kuman terhadap OAT (Obat Anti Tuberkulosis) ,serta memutuskan mata rantai penularan (Ardiansyah, 2012). Lamanya pengobatan pasien TB Paru bergantung kepada kepatuhan dan kedisiplinan dalam minum obat OAT. Selama proses menjalani terapi obat OAT penderita TB Paru mengalami perubahan bentuk fisik menjadi lebih kurus dan tampak pucat, badan lemah dan kemampuan fisik pun menurun (Sulistiyawati, 2012).

Menurut asumsi peneliti bahwa lamanya pengobatan yang dilakukan oleh penderita TB harus dilakukan sampai tuntas hal ini dikarenakan kuman TB dapat aktif kembali apabila terjadinya putus obat dan penderita harus mengulang kembali pengobatan dari awal. Selain itu pengobatan yang tidak cocok dapat menimbulkan efek samping pada penderita TB seperti, tidak nafsu makan, mual, sakit perut dll. Sehingga pengobatan kadang dihentikan dan pasien TB tidak mau untuk melanjutkan pengobatan kembali. Oleh karena itu penderita TB harus waspada jika terdapat efek samping terhadap OAT yang diminum.

Tabel 1.2 Distribusi Frekuensi Dukungan Keluarga Pasien TB Paru di Rumah Sakit Khusus Paru Sumatera Barat Lubuk Alung

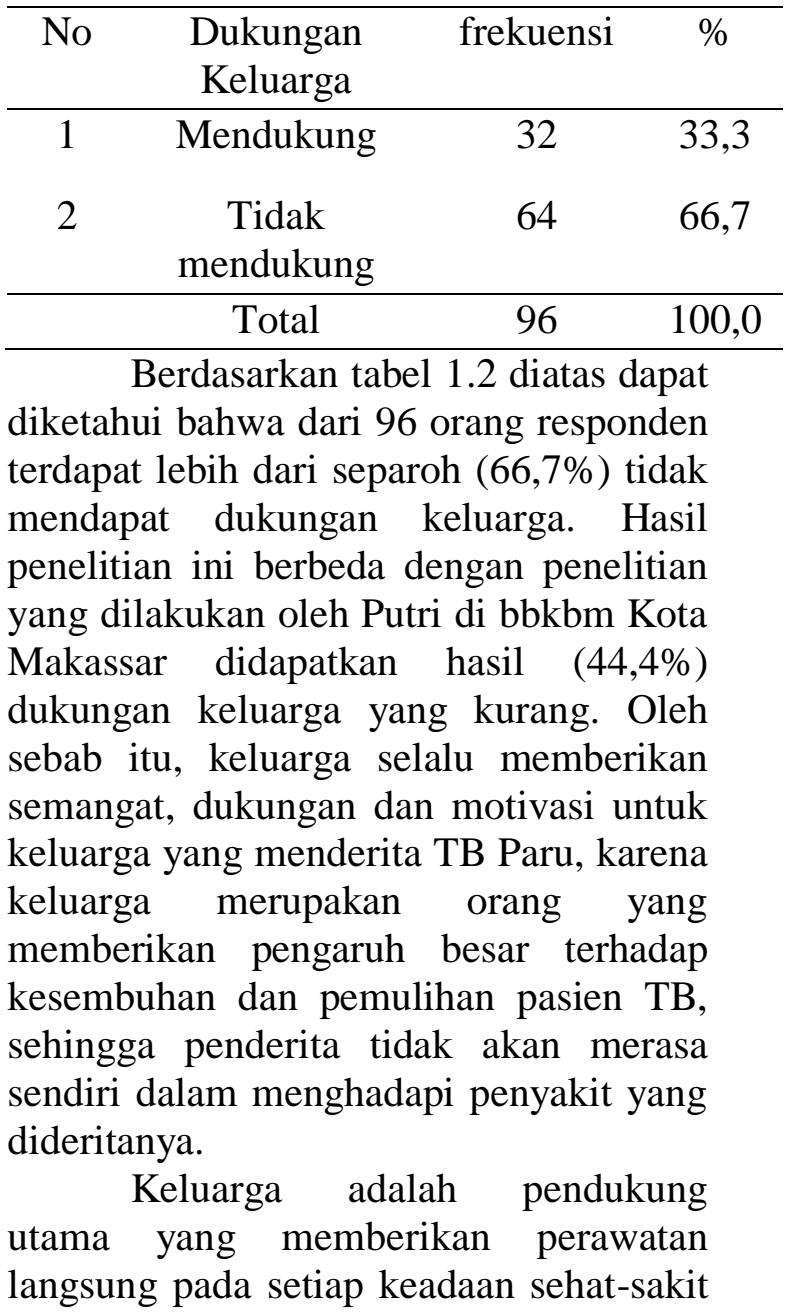


anggota keluarganya. Dalam memberikan dukungan terhadap salah satu anggota keluarga yang menderita suatu penyakit, dukungan dari seluruh anggota keluarga sangat penting dalam proses penyembuhan dan pemulihan penderita (Friedman 2010).

Menurut asumsi peneliti dukungan keluarga penting untuk memotivasi pasien dalam menjalani pengobatan sehingga klien tidak merasa sendiri dalam menjalani pengobatan yang dilakukan. Karena keluarga merupakan orang yang memberikan pengaruh yang besar dalam kesembuhan pasien TB paru. Selain itu dukungan sangat penting diberikan pada penderita TB karena dapat menumbuhkan semangat hidup dan meningkatnya semangat hidup akan meningkatnya kesehatan pasien TB. Hal ini dapat dilihat dari kuesioner setelah dilakukan pelitian dari pertanyaan dukungan keluarga dimana didapatkan responden banyak menjawab kadang-kadang bahkan tidak pernah $(35,0 \%)$ untuk mengingatkan minum obat dan menjawab kadangkadang $(36,1 \%)$ menemani melakukan pengambilan obat di rumah sakit.
Tabel 1.3 Distribusi Frekuensi Depresi

Pasien TB Paru di Rumah Sakit Khusus

Paru Lubuk Alung Sumatera Barat

\begin{tabular}{cccc}
\hline No & Depresi & frekuensi & $\%$ \\
\hline 1 & Tidak & 41 & 42,7 \\
& depresi & & \\
2 & Depresi & 55 & 57,3 \\
\hline & Total & 96 & 100,0 \\
\hline
\end{tabular}

Berdasarkan tabel 1.3 diatas dapat diketahui bahwa dari 96 orang responden terdapat lebih dari separoh $(57,3 \%)$ mengalami depresi.

Hasil penelitian ini hampir sama dengan penelitian yang dilakukan oleh Noerachmi (2014) di Universitas Hasanuddin tentang derajad depresi pada pasien TB didapatkan hasil $(64,4 \%)$ mengalami depresi. Depresi dialami penderita TB akan memperburuk keadaan penderita TB dan akan berdampak pula terhadap kesehatan yang akan di terima oleh penderita TB, maka sebaiknya depresi harus dihindari oleh seseorang yang menderita penyakit kronis khusus nya penyakit TB dengan adanya dukungan dari orang-orang sekitar karena akan membuat seseorang merasa di pedulikan.

Menurut asumsi peneliti depresi dapat ditimbulkan karena lamanya pengobatan yang dilakukan oleh penderita $\mathrm{TB}$, selain itu stigma yang ada dimasyarakat mengenai penyakit TB yang sangat mudah menular, Maka hal tersebut dapat memperburuk keadaan penderita TB karena mereka merasa tidak diterima dimasyarakat seperti dikucilkan dan membuat penderita TB depresi. Hal ini dapat dilihat dari kuesioner $(57,0 \%)$ kadang-kadang pasien TB merasa sendiri dan $(54,1 \%)$ pasien TB merasa sangat takut. 
Tabel 1.4 Distribusi Frekuensi Kualitas Hidup Pasien TB Paru di Rumah Sakit Khusus Paru Sumatera Barat Lubuk Alung

\begin{tabular}{cccc}
\hline No & $\begin{array}{c}\text { Kualitas } \\
\text { hidup }\end{array}$ & frekuensi & $\%$ \\
\hline 1 & Buruk & 60 & 62,5 \\
2 & Baik & 36 & 37,5 \\
\hline & Total & 96 & 100,0 \\
\hline
\end{tabular}

Berdasarkan tabel 1.4 diatas dapat diketahui bahwa dari 96 orang responden terdapat lebih dari separoh $(62,5 \%)$ mengalami kualitas hidup buruk.

Hasil penelitian ini hampir sama dengan penelitian yang dilakukan oleh Hastuti (2014) mengenai hubungan dukungan sosial dengan kualitas hidup pasien TB di Balai Kesehatan Kerja Masyarakat Provinsi Jawa Barat didapatkan hasil $(75,0 \%)$ dengan kualitas hidup rendah. maka kualitas hidup seseorang penderita TB akan berdampak terhadap keberhasilan pengobatan yang dilakukan oleh penderita TB. Semakin baik kualitas hidup seorang penderita TB, maka akan semakin baik pula kesehatan yang akan diterima oleh penderita TB.

Kualitas hidup didefinisikan sebagai persepsi individu mengenai posisi mereka dalam konteks budaya dan sistem nilai dimana mereka hidup dalam kaitannya dengan tujuan, harapan, standar dan perhatian mereka. Defenisi mencerminkan pandangan bahwa kualitas hidup mengacu pada evaluasi subjektif yang tertanam dalam konteks budaya, sosial, dan lingkungan (Nursalam, 2013).

Menurut asumsi peneliti kualitas hidup penderita TB rendah dikarenakan oleh penyakit TB yang diderita akan mempengaruhi kondisi fisik seseorang seperti kelelahan dan dampak dari penyakit TB tersebut akan membuat seseorang tidak mampu melakukan aktivitas seperti biasa seperti bekerja. Selain itu akibat penyakit TB yang diderita penderita TB tidak dapat beristirahat dengan puas karena batuk yang terjadi terus menerus dimalam hari dan menyebabkan penderita kurang beristirahat. Hal ini dapat dilihat dari kuesioner $(43,12 \%)$ tidak puas kemampuan yang tunjukan dalam aktivitas sehari-hari dan $(41,0 \%)$ tidak puas dengan tidur. Kurangnya istirahat pada penderita TB akan membuat sistem imun pada tubuhnya menjadi lemah maka kuman TB akan semakin memperburuk keadaan penderita TB. Hal ini dapat disimpulkan perlunya ditingkatkan kualitas hidup penderita TB agar memperoleh kesehatan yg optimal.

Tabel 1.5 Hubungan Lama Pengobatan dengan Kualitas Hidup Pasien TB Paru di Rumah Sakit Khusus Paru Sumatera Barat Lubuk Alung

\begin{tabular}{cccccccc}
\hline \multirow{2}{*}{$\begin{array}{c}\text { Lama } \\
\text { pengobatan }\end{array}$} & \multicolumn{4}{c}{ Kualitas Hidup } & \multicolumn{2}{c}{ Jumlah } & \\
\cline { 2 - 5 } & \multicolumn{2}{c}{ baik } & \multicolumn{2}{c}{ buruk } & & & P \\
\cline { 2 - 6 } & $\mathrm{f}$ & $\%$ & $\mathrm{f}$ & $\%$ & $\mathrm{f}$ & $\%$ & value \\
\hline Intensif & 27 & 77,1 & 8 & 22,9 & 35 & 100 & 0,000 \\
\hline Lanjutan & 9 & 14,8 & 52 & 85,2 & 61 & 100 & \\
\hline Jumlah & 36 & 37,5 & 60 & 62,5 & 96 & 100 & \\
\hline
\end{tabular}

Berdasarkan tabel 1.5 dapat dilihat bahwa dari 60 pasien TB Paru yang memiliki kualitas hidup yang buruk banyak ditemukan pada pasien TB dengan lama pengobatan lanjutan $(85,2 \%)$ dibandingkan dengan pasien TB yang lama pengobatan intensif (22,9\%). Dari hasil uji statistik ChiSquare didapatkan nilai $\mathrm{p}$ sebesar 0,000 $(\mathrm{p}<0,05)$, dengan demikian dapat diketahui bahwa ada hubungan yang signifikan lama pengobatan dengan kualitas hidup pasien TB Paru di Rumah Sakit Khusus Paru Sumatera Barat Lubuk Alung

Pada penelitian ini ditemukan (22,9\%) kualitas hidup yang buruk pada pengobatan intensif. Hal ini kemungkinan dikarenakan faktor pengobatan intensif dilakukan selama 1-2 bulan dengan meminum OAT setiap hari, maka pasien kadang-kadang merasa jenuh terhadap obat 
yang diminum dan menghentikan pengobatan yang dilakukan, maka hal tersebut dapat memperburuk kualitas hidup penderita TB.

Berdasarkan berbagai penelitian, terbukti bahwa paling banyak hanya $1 / 3$ dari penderita yang minum atau melakukan pengobatan persis seperti yang dianjurkan. Penelitian yang dilakukan oleh Sujayanto (2000), yang mengatakan pengobatan yang tidak teratur bukan hanya tidak menyembuhkan penderita namun juga menyebabkan kekebalan terhadap obat (Asmariani, 2012).

Menurut Asumsi peneliti lama pengobatan yang dijalani oleh penderita TB akan membuat pasien merasa jenuh karena meminum obat yang banyak dan pengobatan yang terputus akan mengulang kembali dari awal. Hal tersebut akan mempengaruhi kualitas hidup pasien TB belum lagi efek samping yang ditimbulkan oleh penderita TB seperti mual, sakit perut dan tidak nafsu makan.

Tabel 1.6 Hubungan Dukungan Keluarga dengan Kualitas Hidup Pasien TB Paru di Rumah Sakit Khusus Paru Lubuk Alung Sumatera Barat

\begin{tabular}{|c|c|c|c|c|c|c|c|}
\hline \multirow{3}{*}{$\begin{array}{l}\text { Dukungan } \\
\text { Keluarga }\end{array}$} & \multicolumn{4}{|c|}{ Kualitas Hidup } & \multirow{2}{*}{\multicolumn{2}{|c|}{ Jumlah }} & \multirow{6}{*}{$\begin{array}{c}\mathrm{P} \\
\text { value } \\
0,000\end{array}$} \\
\hline & \multicolumn{2}{|c|}{ baik } & \multicolumn{2}{|c|}{ buruk } & & & \\
\hline & $f$ & $\%$ & $f$ & $\%$ & $\mathrm{f}$ & $\%$ & \\
\hline Mendukung & 24 & 75,0 & 8 & 25,0 & 32 & 100 & \\
\hline $\begin{array}{l}\text { Tidak } \\
\text { mendukung }\end{array}$ & 12 & 18,8 & 52 & 81,2 & 64 & 100 & \\
\hline Jumlah & 36 & 37,5 & 60 & 62,5 & 96 & 100 & \\
\hline
\end{tabular}

Berdasarkan tabel 1.6 dapat dilihat bahwa dari 60 pasien TB Paru yang memiliki kualitas hidup yang buruk banyak ditemukan pada dukungan keluarga yang tidak mendukung $(81,2 \%)$ dibandingkan dengan dukungan keluarga yang mendukung (25,0\%). Dari hasil uji statistik Chi-Square didapatkan nilai $\mathrm{p}$ sebesar $0,000(\mathrm{p}<0,05)$, dengan demikian dapat diketahui bahwa ada hubungan yang signifikan dukungan keluarga dengan kualitas hidup pasien TB Paru di Rumah Sakit Khusus Paru Lubuk Alung Sumatera Barat.

Pada penelitian ini ditemukan $(25,0 \%)$ dukungan keluarga yang mendukung dengan kualitas hidup buruk. Hal ini kemungkinan dikarenakan faktor lama pengobatan yang dilakukan penderita TB sehingga membuat penderita menjadi malas untuk melakukan pengobatan dan akan mengakibatkan pengobatan terputus dan mengulang kembali pengobatan dari awal, selain itu sikap orang-orang disekitar seperti teman dan masyarakat yang mengucilkan penderita TB akan membuat kualitas hidup penderita TB menjadi buruk.

Hasil penelitian yang dilakukan oleh Putri (2013) tentang hubungan dukungan sosial (keluarga, masyarakat, dan teman) adanya hubungan bermakna antara keluarga dengan kualitas hidup pasien TB.

Menurut asumsi peneliti dukungan keluarga dapat memotivasi pasien TB dalam menjalani pengobatan yang rutin, sehingga pasien akan merasa adanya kepedulian anggota keluarga terhadap keluarga yang sakit. Selain itu dukungan keluarga dapat menurunkan kecemasan dan menghindari rasa putus asa, serta mengurangi rasa takut dari orang sekitar yang mengucilkan penderita TB. Jadi pentingnya dukungan keluarga untuk kesembuhan pasien TB karena dengan adanya dukungan dari keluarga akan meningkatkan kualitas hidup pasien TB, sehingga dengan menigkatnya kualitas hidup pasien TB akan berdampak terhadap kesehatan yang akan diterima oleh penderita TB. 
Tabel 1.7 Hubungan Depresi dengan Kualitas Hidup Pasien TB Paru di Rumah Sakit Khusus Paru Lubuk Alung Sumatera Barat .

\begin{tabular}{|c|c|c|c|c|c|c|c|}
\hline \multirow{3}{*}{ Depresi } & \multicolumn{4}{|c|}{ Kualitas Hidup } & \multirow{2}{*}{\multicolumn{2}{|c|}{ Jumlah }} & \multirow{6}{*}{$\begin{array}{c}\mathrm{P} \\
\text { value } \\
0,000\end{array}$} \\
\hline & \multicolumn{2}{|c|}{ baik } & \multicolumn{2}{|c|}{ buruk } & & & \\
\hline & $\mathrm{f}$ & $\%$ & $\mathrm{f}$ & $\%$ & $\mathrm{f}$ & $\%$ & \\
\hline $\begin{array}{c}\text { Tidak } \\
\text { depresi }\end{array}$ & 32 & 78,0 & 9 & 22,0 & 41 & 100 & \\
\hline Depresi & 4 & 7,3 & 51 & 92,7 & 55 & 100 & \\
\hline Jumlah & 36 & 37,5 & 60 & 62,5 & 96 & 100 & \\
\hline
\end{tabular}

dilihat bahwa dari 60 pasien TB Paru yang memiliki kualitas hidup yang buruk banyak ditemukan pada pasien TB depresi $(92,7 \%)$ dibandingkan dengan pasien TB yang tidak depresi $(22,0 \%)$. Dari hasil uji statistik Chi-Square didapatkan nilai $\mathrm{p}$ sebesar 0,000 $(\mathrm{p}<0,05)$, dengan demikian dapat diketahui bahwa ada hubungan yang signifikan antara depresi dengan kualitas hidup pasien TB Paru di Rumah Sakit Khusus Paru Sumatera Barat Lubuk Alung

Pada penelitian ini ditemukan pasien TB yang tidak depresi $(22,0 \%)$ dengan kualitas hidup yang buruk. Hal dikarenakan faktor obat-obatan yang diterima oleh penderita TB yang dapat menimbulkan efek samping seperti mual muntah terus menerus dan menyebabkan badan klien menjadi kurus sehingga klien mengalami kelemahan dan kondisi fisik yang semakin kurus akan membuat kualitas hidup klien buruk.

Depresi adalah salah satu bentuk gangguan jiwa pada alam perasaan (afektif, mood) yang ditandai dengan kemurungan, kesedihan kelesuan, kehilangan gairah hidup, tidak ada semangat, dan merasa tidak berdaya, perasaan bersalah atau berdosa, tidak berguna dan putus asa (Yosep, 2009).
Menurut asumsi peneliti depresi yang ditimbulkan dari sikap keluarga yang tidak memberikan semangat kepada pasien TB dalam menjalani pengobatan dan membuat pasien merasa sendiri dalam menanggung penyakit yang dialami, hal tersebut akan memperburuk kualitas hidup pasien $\mathrm{TB}$, selain itu depresi juga dapat ditimbulkan karena rasa takut akan kesehatan yang semakin memburuk dari hari ke hari, serta pengobatan yang dijalani terlalu lama maka hal tersebut dapat mempengaruhi kualitas hidup pasien TB. Depresi dapat dihindari apabila penderita TB mendapat dukungan dan selalu optimis akan kesehatan dalam menjalani pengobatan yang bagitu lama.

\section{SIMPULAN}

Lebih dari separoh $(63,5 \%)$ lama pengobatan pasien TB Paru terdapat pengobatan lanjutan. Lebih dari separoh $(66,7 \%)$ pasien TB Paru tidak mendapatkan dukungan dari keluarga. Lebih dari separoh (57,3\%) pasien TB Paru mengalami depresi. Lebih dari separoh $(62,5 \%)$ pasien TB Paru di Rumah Sakit Khusus Paru Sumatera Barat kualitas hidupnya buruk. Terdapat hubungan lama pengobatan dengan kualitas hidup pasien TB Paru di Rumah Sakit Khusus Paru Sumatera Barat. Terdapat hubungan dukungan keluarga dengan kualitas hidup pasien TB Paru di Rumah Sakit Khusus Paru Sumatera Barat. Terdapat hubungan depresi dengan kualitas hidup pasien TB Paru di Rumah Sakit Khusus Paru Sumatera Barat.

\section{UCAPAN TERIMA KASIH}

Dalam menyelesaikan penelitian ini, peneliti telah mendapatkan bimbingan, masukan dan bantuan dari berbagai pihak sehingga pada kesempatan ini peneliti mengucapkan terima kasih kepada : Rumah Sakit Khusus Paru Lubuk Alung Sumatera Barat yang telah memberikan izin dalam proses penelitan. 


\section{DAFTAR PUSTAKA}

Ardiansyah. 2012. Medikal Bedah.

Jogyakarta : DIVA press

Afiyah, R.K (2010). Kualitas hidup perempuan yang mengalami histerektomi serta faktor-faktor yang mempengaruhinya di Wilayah DKI Jakarta : Study Grounded Theory. Thesis. FIK UI.

Dion, dkk, 2013. Asuhan Keperawatan Keluarga Konsep dan Praktik. Yogyakarta : Nuha medika

Departemen Kesehatan, 2013. Laporan Hasil Riset Kesehatan Dasar (Riskesdas) Indonesia, diakses pada 28 Februari 2016

Dhuria, M., Sharma, N. and Ingle, G.K. (2008) Impact of Tuberculosis on the Quality of Life. Indian Journal of Community Medicine, 33, 58-59.

Friedman, M. Marilyn. 2010. Buku Ajar Keperawatan Keluarga Riset teori dan praktek. Jakarta : EGC

Hastuti, Dkk.(2014) Hubungan Dukungan Sosial dengan Kualitas Hidup pada penderita Tuberkulosis Paru di Balai Kesehatan Kerja Masyarakat Provinsi Jawa Barat.

Lubis, N. L. (2009). Depresi : Tinjauan Psikologis. Jakarta: Kencana

Mawaddah. 2013. Gambaran kualitas hidup pasien tuberculosis paru yang menjalani terapi Obat anti tuberculosis di Balai Kesehatan Paru Masyarakat (BKPM). Skripsi. Aceh: Syiah Kuala.

Nazir, K.A (2006). penilaian kualitas hidup pasce bedah coroner yang menjalani pasca bedah pintas rehabilitasi fase III dengan menggunakan SF-36. Jakarta: UI

Niven, N. 2012. Psikologi Kesehatan, Jakarta: EGC

Nursalam, 2013. Metodologi Penelitian Ilmu Keperawatan. Jakarta: Salemba Medika
Putri, R.M. (2013). Hubungan Dukungan social dengan kualitas hidup pasien TB paru di BBKPM Kota Makassar. Ejournal Kesehatan Masyarakat.

Putri, T. S. (2015). Kualitas Hidup pasien TB paru Berdasarkan Aspek Kepatuhan terhadap pengobatan di Puskesmas Padasuka Kota Bandung. Jurnal Keperawatan Aisyiyah, Volume 2(2), 62-63

Ratnasari, Y. N. (2012). Hubungan Dukungan Sosial dengan Kualitas Hidup Pada Penderita Tuberkulosis Paru (TB Paru) Di Balai Pengobatan Penyakit Paru (BP4) Yogyakarta Unit Minggiran. Jurnal Tuberkulosis Indonesia, Volume 8, (2),7-11

Saryono, 2010. Kumpulan Instrumen penelitian kesehatan. Yogyakarta : Nulia Medika

Setyowati, 2008, Asuhan Keperawatan Keluarga konsep dan aplikasi kasus, Edisi Revisi, Yogyakarta: Mitra Cendekia

Smeltzer, Suzanne C. 2001. Buku Ajar Keperawatan Medikal Bedah.Jakarta: EGC. 